\title{
Mambises in Whiteface: U.S. versus Cuban Depictions of Freedom Fighters in the War of Independence against Spain
}

\section{Philip Beidler}

Whether in war, politics, trade, or popular-culture history, the U.S. has always constructed an image of Cuba in terms of its own ideological presuppositions. This has been emphatically true of the racial imagination, from the days of the pre-Civil War annexationists through the current half-century of the Communist era. At no time was this more apparent than when it mattered the most, at the crucial moment of U.S.-Cuban military collaboration concluding the 1895-98 Cuban War of Independence. The racially inflected images produced and circulated at that time - of U.S. military liberators on one hand, and of their Cuban revolutionary counterparts on the other-would prefigure the political and cultural history of the two peoples for the next century and beyond.

Indeed, with the first stirrings of an active Cuban revolutionary independence movement against Spain in the mid-nineteenth century, response in the United States was dictated by a distinct racial subtext. From the highest levels of government to the arena of popular myth, pervaded a fear among supporters and opponents alike that the Cuban Revolution would be in large measure racially "black" - a re-imaging of Toussaint L'Ouverture's Haitian overthrow of colonial mastery a century earlier, but now in a place ninety miles off the southern tip of Jim Crow America. This, too, was an island, after all, so entrenched in its own institutional history of a white minority's enslaving of a vast population of African chattel and their descendants that pre-Civil War Southerners had been tempted to several schemes of annexation-most famously those led by the 
Venezuelan filibustero Narciso López, finally garroted in Havana after a third ill-fated try. As to post-Civil War and post-emancipation attempts by U.S. leaders to manipulate official perceptions of and policy toward the revolutionary patriots, negotiating a racial politics of whiteness versus blackness seems to have been a primary consideration from the outset, with whiteness always visibily figured in the featured role. In this regard, one influential American fresh from the scene felt impelled to assure the American Secretary of State that this was "no nigger rabble." Thus, asserted Paul Brooks, the American owner of a large sugar plantation near Guantanamo in Oriente Province, Cuba, during an 1895 call on Richard Olney, Grover Cleveland's new appointee, at Olney's office in Washington, DC. Brooks, perhaps nervously recalling an earlier anti-Spanish uprising of 186878 begun by the patriot Carlos Manuel de Céspedes by freeing his slaves and exhorting them to join him in revolution, was attempting to give an insider's assessment of the new Cuban military independence movement making its latest renewal of the decades-old war with a recent invasion into western Cuba. At the same time, these were the same bands of rebels Olney had also heard described by Spanish Minister to the U.S. Enrique Dupuy de Lôme as belonging to the lowest social orders. "A rebel victory," Lôme warned Olney, "would devastate the island; independence would presage only anarchy." But there was more than that. It would also be black anarchy. "If this were so," Olney offered in return, "all right-thinking Americans should pray for Spanish success."

Popular culture representations of the era likewise pandered to such racial anxieties, working for a variety of reasons to disguise what might seem to Americans the disquieting racial demographics of a movement that, in fact, from the outset, was never less than 30\% Afro-Cuban and by the time of direct U.S. military involvement was $60 \%$-with the latter figure, by no surprise, corresponding exactly to the late nineteenth-century racial demographics of the island itself. ${ }^{2}$ (As will be seen, in some individual units, the percentage may indeed have run as high as $85 \%$, according to Cuban sources.) This was done mainly by focusing on mediagenic leadership figures in the traditional Western (read Anglo-European and American) revolutionary patriot-statesman mold-a Kosciuszko, a Garibaldi, a Higgins, a Bolivar. Early response in the U.S. was shaped by popular glorification of the distinctly Hispano-Cuban expatriate leader José Martí, a poet, essayist, journalist, and revolutionary philosopher (achieved by downplaying Martí's progressive views of a genuinely postracial revolutionary society). ${ }^{3}$ After Martí's early death in an 1895 skirmish, on the island guerrilla leadership was shared by two inspirational military figures, Máximo Gómez and Antonio Maceo, one hispanic and one mulato, of relatively equal heroic stature, until the latter's early death in battle resulted in his being quickly romanticized offstage to "the Bronze Titan" ("el Titán de Bronce"). In the role of general commanding the insurgent forces, Gómez became the main face of the revolution, fighting on until eventually joined and supplanted, in the American area of operations on the western part of the island particularly, by the aristocratic criollo, Calixto Garcia. Meanwhile, the cultural image of the Spanish suffered 
after the replacement of a relatively humane military proconsul, Arsenio Martínez Campos, with the despicable Valeriano Weyler, remembered mainly to history as inventor of the reconcentrado [civilian concentration camp] policy.

Once the U.S. officially entered the war, the national publicity spotlight shifted almost immediately and entirely away from the Cuban rebels to focus on fighting young American heroes giving their all for the cause: the selfless young U.S. Army lieutenant Andrew S. Rowan carrying the famous message to Garcia; ${ }^{4}$ the martyred bluejackets of the Navy going to their deaths in the treacherous sinking of the U.S.S. Maine; a combined force of cowboys and New York socialites riding and shooting their way to the top of San Juan Hill. (On the topic of race, one might also note the perverse spotlighting at the upper levels of command of celebrated ex-Confederates, including Fitzhugh Lee, son of the great General Robert E. Lee, and of a grizzled old cavalry retread, Fighting Joe Wheeler. In one engagement, with Spaniards rapidly retreating from their positions, the latter was said to have exclaimed, "After them boys! We've got the Yankees on the run!") ${ }^{5}$ Indeed, by the time the U.S. expeditionary forces arrived for their three-month campaign in 1898, they completely monopolized the representational spotlight, and they never gave it up. The war made a number of Americans famous-Teddy Roosevelt, William Randolph Hearst, Richard Harding Davis — and enshrined a host of popular American expressions-filibuster, jingoism, Yellow Journalism, the Rough Riders, the Splendid Little War. It became the war of the celebrity journalist. It was one of the last wars of the great illustrators and the first war of the great photographers. It was actually the first movie/newsreel war. And once it went American, it was blazoned as all-American fighting by all-American boys.

It is now well known that the racial makeup of the American forces in the Cuban-Puerto Rican theater hadn't been a "white" majority; rather, a full twothirds of fighting troops drawn from what were euphemistically termed "colored" ranks. Four major units especially, all heavily engaged in combat, the $24^{\text {th }}$ and $25^{\text {th }}$ Infantry Regiments and the $9^{\text {th }}$ and $10^{\text {th }}$ Cavalry, had been black, although officered by whites, with the latter of these formations widely lauded at the time for their conspicuous bravery during the actions at San Juan and Kettle Hill. ${ }^{6}$ That story has been told. Less known is the corresponding and equally cynical sanitizations and manipulations of images of race in U.S. representations of the Americans' Cuban revolutionary brothers-in-arms. For U.S. audiences, these too had to be as expunged of non-white participation and contributions as those designed to minimize the role of the Buffalo Soldiers. Indeed, if anything, the matter of race in this case seemed even more pressing - Cuban already meant Caribbean, and Caribbean in turn meant criollo, mestizo, mulato and the like. If not all-American, the prototypical Cuban revolutionary patriot, like his leaders, had better be formulated as racially of a predominantly European or at least Euro-Caribbean strain if he was to appeal to Americans to support the troops. The last thing the post-reconstruction Americans north and south wanted to see was yet another insurgent population of post-slavery descendants of New World Africans. Or, as phrased by Hearst illustrator Frederic Remington, for all the 
worth of an exciting Cuban War, there was also the dismal prospect of Americans getting "killed to free a lot of damn n-----s who are better off under the yoke."

Accordingly, from start to finish in this final military stage of the Cuban independence struggle, beginning with the local insurgency phase of the 1880s and extending into the "American" phase of the late 1890s, U.S. representations of rank-and-file Cuban revolutionaries emphasize racial "whiteness." Revolutionary soldiers striking military poses with at least rudimentary uniforms and weaponry tend to be European looking. On occasion, certain figures in support roles may be Afro-Caribbean in feature. When white and black figures intermingle, those in leadership positions are invariably white-hispanic (in the local terminology, "Penninsulare" or "Gallego"), criollo, or, at the very most mestizo. Visible more than a hundred years later on the internet, official military-release propaganda photos in these respects disdain all subtlety. One, entitled "Cuban Soldiers Killed by the Spanish," shows six markedly European looking Hispanic males lying side-by-side in a common grave; another, "Cuban Allies of the U.S.," shows four paramilitary stalwarts in various styles of uniform. They are all completely European in feature. ${ }^{8}$

A parallel outline of racial representations of Cuban soldiery is found in the extensive visual record of the conflict contained in a folio-size, quasi-official commemorative volume of 1898, designed for the parlor or library table and grandly entitled Photographic History of the Spanish-American War: A Pictorial and Descriptive Record of Events on Land and Sea with Portraits and Biographies of Leaders on Both Sides. ${ }^{9}$ A large majority of its 335 plates depict the Caribbean rather than the Pacific theater of war. Of these, precisely two are devoted to the representation of groups of Cuban Revolutionary volunteers in the role of auxiliary troops. One is of a unit of thirty or so infantry soldiers in various states of uniform. Most are distinctly Hispanic in appearance; some appear to be mestizo; in the rear rank are two that appear to be mixed race with African features. The other is entitled "Cuban Scouts." Here, two irregulars are pictured firing their rifles from kneeling positions; barefoot, tattered, ragtag they may be, even these, however, are markedly Euro-Cuban.

In wartime representations of Cuban civilians coming into contact with their North American liberators, such as scenes of "official" crowd gatherings- dockside greetings and farewell parades, victory celebrations, treaty signings, and the like - both populations appear to be well dressed and mainly Caucasian. In many cases they appear quite cosmopolitan and European looking. Boulevardiers pose before storefronts and offices on busy commercial arteries. Senoritas wave from balconies. In contrast, Cuban peasants and refugees, slum dwellers and/ or victims of the reconcentrado program, are almost always black and helpless looking, arrayed against squalid scenes of backwardness and poverty. A notable exception is the first plate of the volume. Entitled "Why We Fought," it is a stark photo-engraving, quite graphic in detail, of three suffering, emaciated, skeletal victims of the reconcentrado system. Here, they are all carefully given dark complexions, but with distinctly sharp, even finely etched Euro-Caribbean features. ${ }^{10}$ 
Newsreels, pioneering experiments in the form, reveal a similar mix. The occasional view is given of a racially miscellaneous Cuban auxiliary soldiery boarding ship from U.S. soil. A scene of arrival in Cuba offers a similarly mixed greeting party. Both films, by virtue of rudimentary technology, have a distinct lack of definition. Facial features and colors of skin and hair remain fairly indistinguishable. A handful of films, styled as re-enactment newsreels, make phenotype more pronounced. Two seem especially notable. One, entitled "Execution of Prisoners," stages the activities of a Spanish firing squad, who march in with their victims, captured rebels, both white and black. They march them up to the wall of a house and rapidly shoot them down. The second is entitled "Spanish Ambush." Here, a revolutionary guerrilla sniper fires from the upper window of a house at a party of Spanish soldiers. It is, rather ludicrously, the same house against the wall of which the execution in the other film is staged. One imagines that the same cast of re-enactors is being used. In this case, the sniper is dragged out, beaten, and summarily executed. His racial identity here seems importantly visible. A simple peasant, guerrilla franc tireur, operating on his own, he is solitary, helpless, and black. ${ }^{11}$

In pronounced and abundant contrast to American representations of the conflict, a rich archive of wartime Cuban photography, illustration, and popular art of the era, readily available to visitors, provides a markedly different overall picture. There, if anything, accounts of the military dimension of the entire latenineteenth century independence struggle frequently highlight the mixed-race character of the independence struggle and the heroism of a distinct group of fighters of color known as the Mambises. (The term itself is an honored one dating from the Independence era and part of the familiar historical vocabulary of most reasonably educated Cubans.) Indeed, an entire freestanding 1998 paperback volume on mixed-race revolutionaries - La Comida in el Monte: Cimarrones, Mambises, and Rebeldes ${ }^{12}$ - is not difficult to find in Cuban bookstores. As with most sources, the political line of the text may be that of the current government; but the relevant illustrations themselves remain distinguished by their historical ubiquity and abundance. Mambise cavalry are totally black. Two Mambise infantryman, oddly mirroring the American "Cuban Scouts" described above, even down to the side-by-side kneeling positions in which they take aim with their rifles, are as deeply black as their counterparts are visibly white. Related representations draw attention to composite criollo, mestizo, mulato, and negro/esclavo mix of fighting units by way of emphasizing the racial brotherhood of fighters in the struggle for revolution. (These images, along with text in consonance with the argument ventured in this article, may also be seen by U.S. viewers at a website maintained by an exile Cuban, Orestes Matacena. $)^{13}$ A second, related text, published in a 2000 Cuban edition by the University of Texas historian Aline Helg — Los Que Nos Corresponde: La Lucha de los Negros y Mulatos por la Igualdad en Cuba 1886-1912, strongly corroborates, on the basis of contemporary photography and illustration, the widespread imaging of multiracial effort in the independence forces. ${ }^{14}$ 
A similar emphasis on racial diversity in the independence soldiery is documented with copious photographic and illustrational evidence in readily available popular histories of a more general nature. An anonymously authored textbook, Historia de Cuba, features a wartime sketch of Maceo as its cover illustration. The combat chapters devoted to the 1895-98 war accordingly feature his heroic leadership with significant pictorial representation of the Mambise contribution. A 2000 school text with the same title by Prof. Jose Canton Navarro features in its sections on the war the leadership of Maceo and illustrates the famous Mambise carga machete, the heroic charge of African irregulars attacking on foot with their lethal machetes and slaying heavily armed and uniformed Spaniards hand-to-hand. The 1995 Heroes de la Independencia de Cuba by Paul Rodriguez and the 1994 Dias de la Guerra Chronologica by Raul Izgquierdo Canosa both approach the 1895 war with a focus on major revolutionary political figures and commanders. Both give copious attention to the leadership of high-ranking black officials, nearly all of them pictured, including Antonio Maceo and his brother Jose, as well as other mixed-race or black commanders such as Sanchez, Valdiva, Tejera, Molina, and Bandera. Of the twenty-seven major generals shown in portraits by Canosa, seven are mulatto or negro. ${ }^{15}$

For conclusive evidence on the point, a text that surely seems as definitive as any concerning wartime representations of Cuban revolutionary fighters of the 1895-98 war is that assembled by Marta Casals Reyes and Jorge Garcia Hernandez, entitled Catalogo de Fotos de la Guerra de Independencia de 1895 and taken from the records of the official Fototeca del Archivo Nacional de Cuba. Here the record of contemporary photography and photo-illustration is compiled, cataloged, and described, with a rich selection of images. Across a wide array of archival war photographs, the mixed-race military effort continues to reveal itself in image after image. In some, the combatants are nearly all dark-skinned, discernibly mulatto or negro. In others, they preponderate toward gallego/penninsulare, criollo, mestizo. Most of the time they are racially diverse: black, brown, white, in their camps, assembling to go into battle, or being memorialized in its aftermath. In picture after picture, they are all depicted in a collective identity, with the sole legend at the bottom of many of the photographs, simply reading "Jefes, officiales, y soldados del Ejercito Liberatador."

A similar proliferation of multiracialism pervades the larger cultural symbologies of history and art familiar to most Cubans. In Havana's Palacio de los Capitanes Generales, for instance, one large chamber features extensive displays of military artifacts and memorabilia, centered on the heroic leadership of three major figures. Máximo Gómez, Antonio Maceo, and Calixto Garcia. The room is dominated by the wall-sized combat painting by the great early twentiethcentury Cuban artist, Armando G. Menocal, The Death of Maceo. The latter is further augmented by major works among the fifteen or so Menocals displayed in Museo Nacional de Bellas Artes (Cuban Section). One, entitled Máximo Gómez en Campaña, features the general with a command and staff group of nine figures, including one black and two mulatto. Another is the artist's rendering of a 
furious carga al machete, with twenty dark Mambi fighters charging past a fallen white commander with stern bravery. Another lift from wartime photography is a depiction of Caballaria Mambisa (Mambise Cavalry). Of fifteen Afro-Cuban figures, three mulato/negro riders have complete, personalized facial features; the rest carry African faces hauntingly in shadow.

As to historical genealogies of Cuban independence struggle, in a walk along the Havana Malecon in 2010, images of Che Guevara, Fidel Castro, and Camilo Cienfuegos fade into the wall while great heroic statues continue to honor a triad of ninteenth-century revolutionary predecessors. At one extreme of the long seawall walk is Calixto Garcia. At the other is Maximo Gómez. In the middle, dominating a park for the children of Havana, is Antonio Maceo. Decorative panels on the side of the pedestal supporting the huge equestrian statue in bronze depict Maceo's humble birth, his black father, and his revered mother, Maria Grajales Coelho, herself a national heroine. The other, with many of the figures represented given African features, emphasizes his liberation of the enslaved. A multitude of figures of statuary attend Maceo on the ascendant pedestal. They are Cubans of all visible races, together. Of the three statues, it is significant that the Revolution left them standing, as they did not many others. One can only infer that they were part of Cuban memory that no one ever thought to deny.

The markedly contrasting "whitening" tendencies of racial selection and valuation in U.S. representations of the war and its aftermath prevailed not just in photography and illustration, but also in major written accounts. A report from the front by the celebrity correspondent Richard Harding Davis, for instance, quickly describes a Cuban patriot contingent included in an American landing force with no references to race (104-05). In contrast, a spotlight paragraph about a personal visit to Garcia specifies a gathering of his supporters and a larger crowd of welcome as comprising "Cubans and negroes"- as if, somehow, these were categories that needed to be separated (106). Garcia himself, in contrast, is pointedly described as "a handsome man, with a white mustache and goatee," who "looks like Caprivi, the German Chancellor" (107).

And then there was his celebrity-politician counterpart, Teddy Roosevelt who, when not playing soldier, fancied himself something of a gentleman historian-journalist, was never one to keep his political opinions a secret-even if perhaps too glaringly close to betraying the secret official line. "The Cuban soldiers were almost all blacks and mulattoes," he observed,

and were clothed in rags and armed with every kind of old rifle. They were utterly unable to make a serious fight, or to stand even against even a very inferior number of Spanish troops, but we hope they might be of some use as scouts and skirmishers. For various reasons this proved not to be the case, and so far as the Santiago Campaign was concerned, we should have been better off if there had not been a single Cuban in the army. They accomplished literally nothing, while they were 
a source of trouble and embarrassment, and consumed much provisions" (Lee 645).

More humane and circumspect, if as conventionally racist, was their star literary counterpart, Stephen Crane, who described the Cuban revolutionaries he saw as "a hard-bitten, undersized lot, most of them negroes, and with the stoop and gait of men who had at one time labored at the soil. They were, in short, peasants - hardy, tireless, uncomplaining peasants - and they viewed in utter calm these early morning preparations for battle" (Stallman 141). The word negro is determining. They are terrible at close-order drill (142). They are stolid with their wounds:

\begin{abstract}
And - look - there fell a Cuban, a great hulking negro, shot just beneath the heart, the blood staining his soiled shirt. He seemed in no pain; it seemed as if he were senseless before he fell. He made no outcry; he simply toppled over, while a comrade made a semi-futile grab at him. Instantly, one Cuban loaded the body upon the back of another and then took up the dying man's feet. The procession that moved off resembled a grotesque wheelbarrow. No one heeded it much. A marine remarked: "Well, there goes one of the Cubans." (145)
\end{abstract}

They are terrible shots: "The Cubans, who cannot hit even the wide, wide world" (146). To Crane's credit, this undertone of race could prompt an explicit commentary. "Cubans Held in Contempt," he would headline one item (181). "To put it shortly," he admitted,
"both officers and privates have the most lively contempt for the Cubans. They despise them. They came down here expect- ing to fight side by side with an ally, but this ally has done little but stay in the rear and eat army rations, manifesting an indifference to the cause of Cuban liberty which could not be exceeded by one who had never heard of it." (181)

Cowardice, ineptitude, indiscipline, laziness, beggarliness (181): as coded terms of racial contempt for a non-white, non-western, non Anglo-European ally - these could have been written in Saigon seventy years later. The difference here would have been the unspoken word: "nigger," as opposed to, seventy-five years later, "gook." 16 If one knows where to look there certainly seems to have been a good deal of it going around in the Army at the time. "The valiant Cuban!" recalled one sadly representative American lieutenant. "He strikes you first by his color. It ranges from chocolate yellow through all the shades to deepest black with kinky hair." Matched with this, he went on, is "the furtive look of the thief" and bodily infestation "with things that crawl and creep, often visibly, over this 
half-naked body, and he is accustomed to it that he does not even scratch" (Parker 76-77). Today, perhaps, in Baghdad and Kabul, where the operating expressions would be "raghead" or "haji," the attitude remains essentially the same.

On the other hand, analogies to recent American involvement in notoriously undecided or even lost insurgent struggles, should not be allowed to blind the reader to the actually relatively strong Cuban Revolutionary position in 1898 against their Spanish overlords on the eve of official American commitment. Unlike the South Vietnamese, or the current provisional governments in Iraq and Afghanistan, the Cubans were well on the way to winning the war before the Americans arrived. In fact, there were no real attempts at coordination with Revolutionary forces, no matter what their racial makeup. Any such official yoking, after all, would have required some eventual diplomatic recognition of revolutionary elements. Completely ignored were the voices of any who considered themselves fighting for racial as well as conventional political liberty. Unheard, for example, is the voice of Afro-Cuban Esteban Montejo, who fought the war, he said, because:

it wasn't fair that so many jobs and so many privileges happened to fall into the hands of the Spaniards alone. It wasn't fair that for women to work they had to be daughters of Spaniards. None of that was fair. You never saw a black lawyer because they said that blacks were only good for the forest. You never saw a black teacher. It was all for the white Spaniards. Even the white criollos were pushed aside. I seen that myself. A night watchman, whose only job was to walk around, call out the hour, and put out the candle, had to be a Spaniard. And everything was like that. There was no freedom. That's why a war was necessary. (171)

But if he expected things to change under the auspices of "La Intervención," he continued, he was quickly disabused of such hope. "The Americans didn't like the negroes much," he said.

They used to shout 'Nigger, nigger,' and burst out laughing. If you joined in the joke they went on trying to annoy you, but if you took no notice they left you alone. They never tried to interfere with me; I couldn't stomach them, and that's a fact. I never joked with them, I gave them the slip whenever I could. After the war ended the arguments began about whether the negroes had fought or not. I know that ninety-five percent of the blacks fought in the war, but they started saying only seventy-five per cent. Well, no one got up and told them they were lying, and the result was the negroes found themselves 
in the streets - men brave as lions, out in the streets. It was unjust, but that's what happened. (216)

Revolution in the name of human fairness: what, according to American propaganda, could be more American? - but only if it turned out to be cleansed of any associations with a "nigger rabble." (Nor did postwar policies prove to be any exception, with blacks systematically excluded from government and administrative posts. More than a half-century later, $95 \%$ of exiles during the 1959 Revolution turned out to be white - beneficiaries of new, Americanized versions of older colonial regimes presiding over a population never less than $60 \%$ black.)

What did this all mean to Americans at the time? To black Americans, much more deeply in the know about racial configurations of the conflict than their white counterparts, through alternative sources of information - not least a network of African American newspapers - war news meant a lot. What seems unquestionably a choice at highest policy levels, the sending of significant elements of black troops to fight a black war, may have been a cynical maneuver well disguised at the level of general public reporting. The black troops and/or black Americans seem to have understood this. But they still took great interest and even pride in the war's dimension as a "negro" struggle. (Buckley 142). "Most black Americans supported the war." Black newspapers heralded the accomplishment of black units. In the white press, occasional identification of units as "colored," with occasional braveries credited as proving them worthy of their white counterparts, became notable items (Davis 244). Even in condescension mixed with happy-go-lucky caricature, readers fed on scraps from the newspaper table of the estimable Richard Harding Davis: "The negro soldiers established themselves as fighting men that morning," he concluded after one action, "and the chuckles they gave as they shoved the cartridges into their belts showed that, though they did not have food or water, so long as they had ammunition they were content" (244). "Cuba" itself, considered in some totality of the cause of freedom, was embraced as "a 'colored' country," and the fallen Maceo, deemed the African father of "Cuba Libre," became a martyr to black Americans. Accordingly, the cause could also make an occasion for black protest. "Talk about fighting and freeing poor Cuba and of Spain's brutality; of Cuba's murdered thousands, and starving reconcentradoes," wrote one black chaplain/ editorialist back to a Cleveland newspaper. "Is America any better than Spain? Has she not subjects in her very midst who are murdered daily without a trial of judge or jury? Has she not subjects in her borders whose children are half-fed and half-clothed, because their father's skin is black?"17

To white Americans, Cuba became a case of the new national business of imperialist muscle-flexing as usual-picking up the white man's burden by cleaning up dirty little wars and installing white men's surrogates. As in the Philippines, where Hispano-Filipino elites were established as a permanent ruling class above the masses of native peoples, in Cuba, Euro-Caribbeans were 
installed over descendants of African slaves. And so it would remain well into the new century and beyond.

Cuba Libre! That had been the Revolutionary rallying cry from the beginning. It had been a cry of all Cubans, not least the most eager and brave coming from those most emancipated. This special role of Afro-Cubans was realized early on by the sainted Martí. "The black man has drawn his noble body to its full height and is becoming a solid column for his native liberties," he proclaimed. "Others fear him; I love him" (James 246). Ultimately, the United States decided that the complexion of the face of the Revolution should be otherwise. And they made it happen that way in photographs, movies, and words. The point is perhaps best illustrated by a popular propaganda poster of the era, itself with the title Cuba Libre! The focal figure is a beautiful, tortured, suffering woman, gowned in the Cuban Revolutionary flag, confined to a dungeon but standing free of her chains, arms upraised, appealing for rescue from the brutal oppressor. A Caribbean passionaria, one might call her. She is the very figure of Liberty, albeit with a certain Latin exoticism to be sure: criolla, possibly mestiza, at the limits of racial fantasy, dusky tragic mulatta. As to classical beauty and outline of face and feature, nonetheless, she could not be whiter. ${ }^{18}$ In a war that was very much about race, the order of the day remained erasure.

\section{Notes}

1. Ivan Musicant, Empire by Default: The Spanish-American War and the Dawn of the American Century (New York: Henry Holt, 1998), 83.

2. Ibid., 39. According to some Cuban accounts, the percentage in individual units may have run as high as $85 \%$. The data cannot be confirmed. As will be seen, however, recurrent images from contemporary Cuban photo archives, discovered in the course of my primary research, suggest that mixed-race formations seem to have been customary among the common revolutionary soldiery. See also note 13 below.

3. For a succinct, clear account of Marti's manifest commitment, in word and deed, to the goal of "a color blind patria," see Evan Thomas, The War Lovers: Roosevelt, Lodge, Hearst, and the Rush to Empire, 1898 (New York: Little, Brown, 2010), 105.

4. The title, now largely forgotten in its specific context, came from a 1899 inspirational essay by popular journalist Elbert Hubbard based on Rowan's faithful fulfillment of a wartime mission given directly by President William McKinley to contact the rebel leader at all costs at his headquarters "somewhere in the mountain vastness of Cuba-no one knew where." Rowan himself became famous for having completed such a mission and wrote his own Hubbard-like account. A motivational classic of the era, the original "Message to Garcia" appeared first in Hubbard's Philistine Magazine and was frequently reprinted in book and pamphlet forms. The point of Hubbard's essay was the shortage of such Rowan-like figures in the world of work and business. "Civilization is one long anxious search for just such individuals. Anything such a man asks shall be granted; his kind is so rare that no employer can afford to let him go. He is wanted in every city, town and village-in every office, shop, store and factory. The world cries out for such: he is needed, \& needed badly-the man who can carry a message to Garcia." http://www.birdsnest.com/garcia.htm.

5. Frank Freidel, Splendid Little War (Boston: Litte, Brown, 1958), 106.

6. Ibid, 173.

7. Thomas, 159. In a broader racial connection, it should be noted that, meanwhile, in the far Pacific, the identical word was being regularly applied to Spanish-American era Filipinos. The differences in racial reference, on the other hand, could not have been more clear. In Cuba, the usage was nearly always pure Simon Legree, Pap Finn, American English. In the Philippines, applied to native peoples of various Asian racial descents, it bespoke a more general kind of Anglo-Saxonism affected by budding American imperialists in imitation of their insouciant British counterparts. For a detailed study of cultural and gendered racializations of native Asian peoples of the Philippines during the era, see Vincente L. Rafael, "White Love: Surveillance and Nationalist Resistance in the U.S. Colonization of the Philippines," in Kaplan and Pease, 185-218. 
8. http://www.havanajournal.com/gallery/image

9. New York: E.J. Stanley, 1898.

10. For a parallel study of prewar, wartime, and postwar racial imagings of the Cuban people, see the magisterial study of newspaper and magazine illustration from the era in chapters two and three of Louis A. Perez, Jr.'s Cuba and the Imagination: Metaphor and the Imperial Ethos (Chapel Hill: University of North Carolina Press, 2008). With almost uncanny exactitude, prewar and wartime images of suffering Cubans are almost uniformly images of whiteness - starving mothers and children, imperiled, virtuous, often voluptuous womanhood. Postwar images in contrast plunge almost immediately into racist caricatures of blackness, with a distinct preference for sambos and pickanninies.

11. http://www.memory.loc.gov/ammem/sawhtml/sawhome.html, 2008.

12. Havana: Fundacion de la Naturaliza y el Hombre, 1998.

13. http://www.orestesferrara.com/orestes ferrara_contents.htm

14. La Habana: Imagen Contemporanea, $\overline{2} 000$.

15. All such post-1959 source materials available in Cuba must be understood as being issued with government approval, including a pronounced desire to promote the image of a postracial society as a goal of Cubans throughout their revolutionary history. On the other hand, I believe a particular claim should be made for the documentary volume made available to me by the photographer Julio Larramende as part of a publication series issued by the Fototeca. To be sure, the Fototeca enjoys government sponsorship, but it also enjoys a certain amount of independence, as do other emerging cultural institutes and centers, as a serious center for the study of the history of Cuban photography.

16. According to a number of persuasive accounts, though most prominent in soldier slang of the Korean and Vietnamese conflicts, the particular slur itself may have originated in the Philippine theater of the Spanish-American war and/or in the ensuing counter-guerrilla campaigns of the islands during the early 1900s. "Gu gu" has been suggested as the origin, from a Tagalog word for slippery; "goo-goo" eyes may have been associated with Filipina prostitutes. For a detailed etymology in these terms, anchored in a larger study of race and empire in U.S.-Philippine history, see Paul A. Kramer, The Blood of Government: Race, Empire, the United States, and the Philippines (Chapel Hill: University of North Carolina Press, 2006), 127-28.

17. http://www.spanamwar.com/AfroAmericans.htm. For a detailed study of ensuing developments in such reporting of African American attitudes, see David J. Hellwig, "The African-American Press and United States Involvement in Cuba, 1902-1912," in Between Race and Empire: African Americans and Cubans before the Cuban Revolution," edited by Lisa Brock and Digna Castaneda Fuertes (Philadelphia: Temple University Press, 1998), 70-84. On a related note, African American soldiers in the Philippines are documented as having written home in significant protest of the widespread use of "nigger," frequently in their presence, to describe native peoples of the islands. See Kramer, Blood of Government, 228-29.

18. Donald M. Goldstein and Katherine V. Dillon, eds., The Spanish-American War (Washington: Brassey's, 2000).

\section{Works Cited}

American Memory: The Spanish-American War in Motion Pictures. $<\underline{\text { http://www. }}$ memory.loc.gov./ammen/sawhtml/sawhome.html>, 2008.

Anon. Historia de Cuba. Habana: Instituto del Libro, 1970.

Buckley, Gail. American Patriots: The Story of Blacks in the Military from the Revolution to Desert Storm. New York: Random House, 2001.

Canosa, Raul Izquierdo. Dias de la Guerra Chronologica. Habana: Editora Politica, 1994.

Crane, Stephen. The War Dispatches of Stephen Crane. Ed. R.W. Stallman and E.R. Hagermann. New York: NYU Press, 1964.

Davis, Richard Harding. The Cuban and Porto Rican Campaigns. New York: Scribners, 1898.

Freidel, Frank. Splendid Little War. Boston: Little, Brown, 1958. Goldstein, Donald M. and Katherine V. Dillon, eds. The Spanish-American War. Washington: Brassey's, 2000.

Havana Journal. < http://www.havanajournal.com/gallery/image>, 2013. 
Helg, Aline. Lo Que Nos Corresponde: La Lucha de los Negros y Mulatos por la Igualdad en Cuba, 1886-1912. La Habana: Imagen Contemporanea, 2000.

James, Winston. Holding Aloft the Banner of Ethiopia: Caribbean Radicalism in Early 20 $0^{\text {th }}$ Century America. London: Verso, 1998.

Jimenez, Antonio Nunez. La Comida in el Monte: Cimarrones, Mambises, and Rebeldes. Havana: Fundacion de la Naturaliza y el Hombre, 1998.

Lee, Fitzhugh, Joseph Wheeler, Theodore Roosevelt, and Richard Wainwright. Cuba's Struggle Against Spain with the Causes for American Intervention and a Full Account of the Spanish-American War, including Final Peace Negotiations. New York: American Historical Press, 1899.

Montejo, Esteban. The Autobiography of a Runaway Slave, ed. Miguel Barnet, tr. Jocasta Innes. New York: Pantheon, 1968. Excerpted in Mellen, Jim, "Cuban Soldiers in the Spanish-American War." Small Planet Communications. $<$ http://www.smplanet.com/imperialism/cuban.html $>, 2012$.

Musicant, Ivan. Empire by Default: The Spanish-American War and the Dawn of the American Century. New York. Henry Holt, 1998.

Novarro, Jose Canton. Historia de Cuba. Habana: SI-MAR, 1996.

Parker, John H. The Gatlings at Santiago. Middlesex, U.K.: Echo, 2006.

Photographic History of the Spanish-American War: A Pictorial and Descriptive Record of Events on Land and Sea with Portraits and Biographies of Leaders on Both Sides. New York: E.J. Stanley, 1898.

Powell, Anthony L. "An Overview: Black Participation in the Spanish American War." Spanish-American War Website. < http://www.spanamwar.com/ AfroAmericans.htm>, 2012.

Reyes, Marta Casals, and Jorge Garcia Hernandez, ed. Catalogo de Fotos de la Guerra de Independencia de 1985. Habana: Fototeca del Archivo Nacional de Cuba, 1996.

Rodriguez, Raul. Heroes de la Independencia de Cuba. Buenos Aires: Casa de Amistad Argentina-Cubana, 1995. 
